Article

\title{
Lifetime Degradation Cost Analysis for Li-Ion Batteries in Capacity Markets using Accurate Physics-Based Models
}

\author{
Ahmed Gailani *(-), Maher Al-Greer ${ }^{\circledR}$, Michael Short ${ }^{\circledR}$, Tracey Crosbie and Nashwan Dawood \\ School of Computing, Engineering and Digital Technologies, Teesside University, Middlesbrough TS1 3BX, UK; \\ M.Al-Greer@tees.ac.uk (M.A.-G.); M.Short@tees.ac.uk (M.S.); T.Crosbie@tees.ac.uk (T.C.); \\ N.N.Dawood@tees.ac.uk (N.D.) \\ * Correspondence: A.Gailani@tees.ac.uk; Tel.: +44-(0)-16-4221-8121
}

Received: 13 May 2020; Accepted: 29 May 2020; Published: 2 June 2020

check for updates

\begin{abstract}
Capacity markets (CM) are energy markets created to ensure energy supply security. Energy storage devices provide services in the CMs. Li-ion batteries are a popular type of energy storage device used in CMs. The battery lifetime is a key factor in determining the economic viability of Li-ion batteries, and current approaches for estimating this are limited. This paper explores the potential of a lithium-ion battery to provide $\mathrm{CM}$ services with four de-rating factors $(0.5 \mathrm{~h}, 1 \mathrm{~h}, 2 \mathrm{~h}$, and $4 \mathrm{~h}$ ). During the $\mathrm{CM}$ contract, the battery experiences both calendar and cycle degradation, which reduces the overall profit. Physics-based battery and degradation models are used to quantify the degradation costs for batteries in the $\mathrm{CM}$ to enhance the previous research results. The degradation model quantifies capacity losses related to the solid-electrolyte interphase (SEI) layer, active material loss, and SEI crack growth. The results show that the physics-based degradation model can accurately predict degradation costs under different operating conditions, and thus can substantiate the business case for the batteries in the CM. The simulated CM profits can be increased by $60 \%$ and $75 \%$ at $5{ }^{\circ} \mathrm{C}$ and $25^{\circ} \mathrm{C}$, respectively, compared to empirical and semiempirical degradation models. A sensitivity analysis for a range of parameters is performed to show the effects on the batteries' overall profit margins.
\end{abstract}

Keywords: capacity market; degradation cost; physics-based modelling; de-rating factors

\section{Introduction}

The threat of climate change due to global warming has encouraged many countries to adopt policies to increase reliance on renewable energy sources (RES) in their electricity networks. The EU policies require European countries to increase the energy produced by RES by $20 \%$ by 2020 and $27 \%$ by 2030 [1]. The total world renewable energy generation capacity increased by $14.5 \%$ in 2019 [2]. The intermittent nature of RES [3], along with fast energy demand growth [4], raises considerable energy security concerns [5,6]. Driven by such concerns, several multidimensional approaches have been used to ensure adequate and cost-efficient power systems. These include enabling innovative technologies such as energy storage [7-9], improving market design [10,11], and enhancing system operation [12].

The introduction of the capacity markets (CMs) to improve the electricity market design is seen as an effective solution to enabling the integration of RES in electricity networks. As such, CMs have been implemented in many countries, including the US [13], Latin America [14], and Europe [15]. The aim of this is to adequately remunerate new electrical generators, reduce investment risks, and avoid electricity blackouts. Many of the new generators providing CM services use lithium-ion 
batteries (LIBs) due to their high energy density and long life cycle [16]. Earlier work has illustrated that batteries can enhance new generators by providing capacity services ranging from $40 \%$ to $100 \%$ of their nameplate capacity, thus reducing the number of shortage events (SEs) in the CM [17,18]. Another study have found that the revenue from energy storage devices can be tripled if LIBs are utilized to provide energy reserve services in the electricity markets [19]. Further work has found that batteries participating in the $\mathrm{CM}$ can secure substantial upfront revenue, while only marginally reducing profits from other markets [20].

LIB degradation is the main factor in determining the operational cost [21]. As such, there is a need to assess the economic viability of LIBs in the CM. Once a battery wins a CM contract, it must remain ready to discharge during electricity SEs, which may leave the battery at $100 \%$ charge status for a long period, thus increasing its degradation cost [22]. Failure to deliver the contracted CM capacity when needed may result in penalties [23]. However, many previous studies aiming to evaluate the viability of LIBs in different grid applications either did not account for the degradation cost or no clear or accurate degradation model was used. Earlier research in [24-26] show how different batteries can provide ancillary services to the grid, such as short time operating reserves or capacity reserves, but this work did not consider battery degradation. Other research in [20,27-29] evaluated the applicability of LIBs to provide different services, such as the spinning reserve, frequency response, and peaking capacity; however, once again these works did not include a clear battery degradation model. Many other studies have accounted for degradation costs by including an empirical LIB degradation model [30-34]. These models are based on mathematical functions that provide good fitting for the experimental data used. While empirical and semiempirical models are computationally efficient, they are usually based on limited battery operating conditions, thus making extrapolation inaccurate beyond the used dataset $[35,36]$. This inaccuracy can be mitigated to some extent if a wide range of operating conditions are tested.

Other empirical degradation models used often ignore important degradation details. For instance, earlier research in [37] presents a nonlinear degradation model to account for the degradation cost in the day-ahead market, while ignoring calendar degradation. However, in an actual island grid-connected battery operating for three years, it was found that the battery was in an idling position for $20 \%$ of the total operating time [38]; thus, ignoring calendar degradation may lead to erroneous results. Several other works either did not consider temperature effects on battery degradation [39,40], overlooked state of charge (SoC) effects during calendar degradation [41], or accounted for the impact of depth of discharge (DoD) only [42].

Other works consider the effects of degradation costs using advanced physics-based LIB models. The authors in [43] present a modelling framework for grid-connected batteries using a physics-based single-particle model (SPM), considering capacity fade due to solid-electrolyte interphase (SEI) layer mechanisms. Similarly, the work in [44] presents a physics-based SEI layer degradation assessment for LIBs in a grid-connected PV system using SPM. Recent research [45] used different LIB models, including SPM, to optimize batteries in order to provide energy arbitrage services to the grid, and concluded that the expected revenue could be substantially improved using more accurate battery degradation models. However, all the aforementioned works either did not consider the CM, considered it without de-rating factors, or quantified it with only one degradation mechanism (SEI layer only) in the economic analysis, while overlooking the impacts of other possible degradation effects, such as active material loss and crack growth [46].

This paper improves on the previous economic studies by quantifying the degradation costs for three degradation mechanisms for LIB cells in the CM using a physics-based degradation model coupled with a pseudo two-dimensional LIB cell model. These three degradation mechanisms are SEI layer growth, active material (AM) loss, and SEI layer fracture. Furthermore, this work considers several CM de-rating factors, which is seen as essential in improving the business case for energy storage in the CM [47]. Ultimately, this work mitigates the limitations mentioned in a recent study [48], 
which concluded that empirical and semi-empirical degradation models are unable to capture battery degradation effects at lower temperatures, such as $5^{\circ} \mathrm{C}$.

\section{Capacity Market Fundamentals}

The reliability of liberalized electricity markets has been questioned due to increasing energy demands, the decommissioning of conventional power plants (i.e., coal), and the steady growth of RES. In particular, many policymakers argue that the current energy-only markets may not ensure resource adequacy [49]. One issue is that the energy-only market neglects the energy adequacy problem, because it assumes that the energy demand and supply are always balanced (quantity supplied = quantity needed). Thus, when the supply side becomes scarce, there must be a load reduction from the demand side to ensure market clearance. However, due to the inelastic nature of the demand side and rational customer responses, electricity markets do not guarantee a demand response or market clearance [50].

Another reason for the energy-only market failure is its inefficiency during electricity blackouts [51]. If there is a blackout similar to the one that happened in the UK in 2019, which affected over 1 million customers [52], then there is at least one supplier that does not have power to sell at any price, as illustrated in Figure 1a. Despite the scarce capacity and the peak demand, generators do not earn money in the blackout events [48].
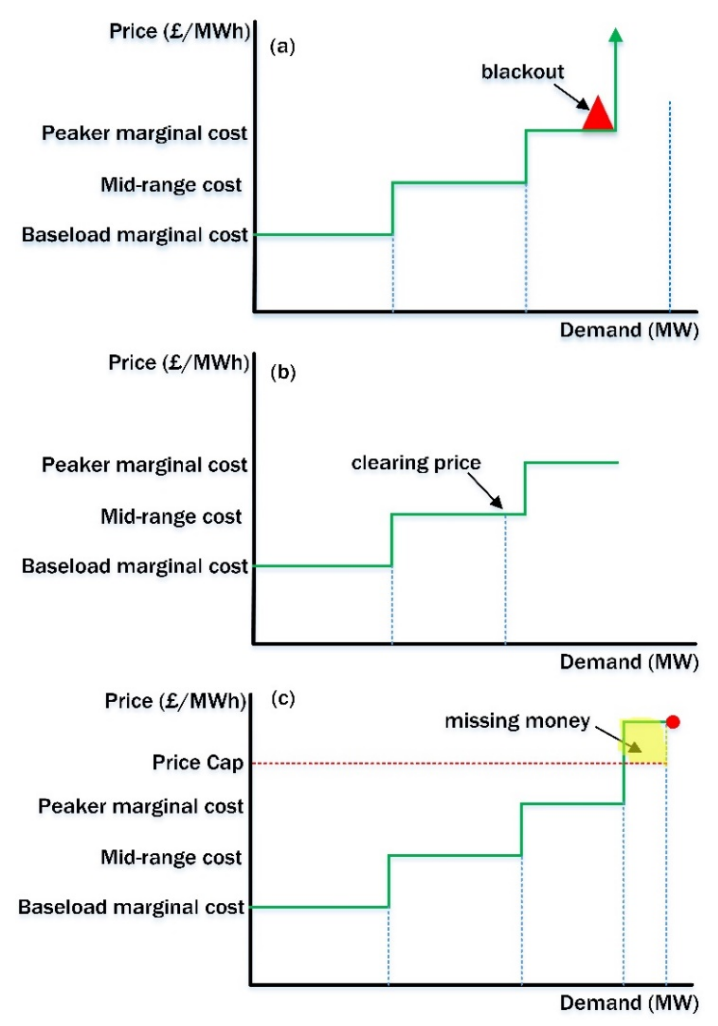

Figure 1. Energy price and demand for different generators during: (a) blackout; (b) normal operation; (c) period of scarcity.

Nevertheless, even if there are no generation adequacy issues, a "missing money" problem will exist in both normal operating conditions and scarcity periods. In normal operating conditions, where the demand quantity is below the peak available capacity (shown in Figure 1b) and the market is competitive, some generators, such as the peakers (plants operating only at high demand), cannot earn sufficient revenue beyond covering their operating costs [49]. Therefore, they may not cover their capital investment cost. In scarcity periods, as shown in Figure 1c, all generators may charge high scarcity prices (red dot), which in real cases can be 367 times higher than the average price [53]. However, market power can be exercised in scarcity periods, even by small generators (see [54]), 
therefore triggering regulatory intervention. Regulators usually set the scarcity prices low to mitigate market power abuse, thus creating the missing money problem depicted in Figure 1c. Since the investment in new capacity to increase the reliability of the supply side depends on the scarcity prices, energy-only markets, therefore, do not provide the incentives needed to increase capacity.

A well-designed CM can mitigate the issues of market power and missing money by determining the adequate level of supply capacity needed. This can be done by designing a capacity auction for generators to determine the scarcity price required to secure an adequate level of capacity, as set by the regulator, in order to reduce the number of shortage hours. The market is open to new and existing generators, considering the investment level needed in the new generators. The result is that the market discovers the true value of the scarcity price corresponding to the optimal level of capacity, while the regulatory intervention is limited to only control the level of the capacity needed.

For several reasons, energy storage devices may have limited discharge capacity (for example, degradation). Therefore, CMs (in the UK, Germany, France, Italy, Ireland, and Denmark) have introduced de-rating methodologies to account for the percentage of firm capacity they can supply during shortage periods [55]. Fraunholz et al. [56] found that the choice of a suitable de-rating factor is challenging and may affect batteries' market competitiveness. Figure 2 depicts the number of batteries providing $\mathrm{CM}$ services in the current $\mathrm{UK} \mathrm{CM}$ with different de-rating factors. The de-rating factors are $\mathrm{CM}$ design parameters that are used to measure the net contribution of energy-limited devices such as energy storage and energy security. It can be seen that there is an increased interest in obtaining higher de-rating factors, such as $3 \mathrm{~h}$ or $4 \mathrm{~h}$ durations. This study considers a real-life scenario, in which LIBs are utilized to obtain $0.5 \mathrm{~h}, 1 \mathrm{~h}, 2 \mathrm{~h}$, and $4 \mathrm{~h}$ de-rating factors.

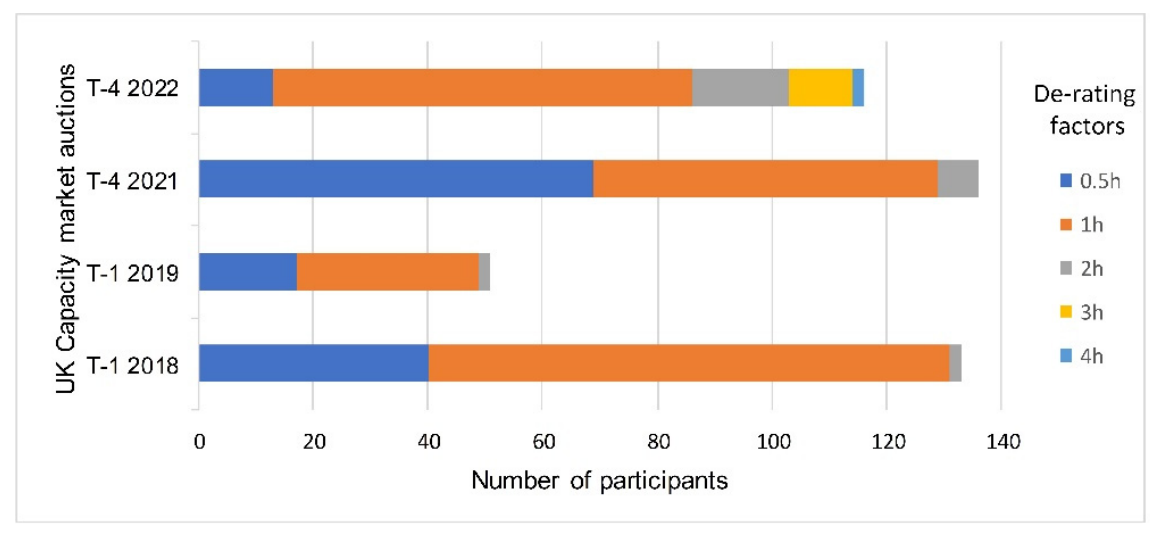

Figure 2. De-rated batteries in the UK capacity market for the period ranging from 2018 to 2022 [55].

\section{Methods}

\subsection{Problem Setup}

This study models battery degradation for LIBs used to provide a CM service to the UK grid operator over a one-year contract using a physics-based model. During the contract period, many simultaneous degradation mechanisms can affect the battery performance, resulting in a degradation cost. As illustrated in Figure 3, when the CM's contract begins, the battery should provide reserve services to the grid and be ready to respond to electricity SEs. Therefore, in the absence of SEs, the calendar battery degradation can be quantified. During SEs, and depending on their duration, the obligation capacity will be calculated for each de-rated battery. The duration of the event and the obligation capacity amount is updated at each settlement period $(30 \mathrm{~min})$. Then, a physics-based battery model is used to discharge the required capacity. The operating conditions of the battery, such as the temperature, are then fed to the degradation model to quantify the cycle degradation and update the initial capacity in the model. Afterwards, depending on the amount of generated power, the penalties and overpayment can be quantified to obtain the overall revenue. The battery capacity 
and the de-rating factors used in this study are shown in Table 1, which are in line with the current batteries participating in the CM [57]. The CM parameters used in this study are given in an earlier study [48].

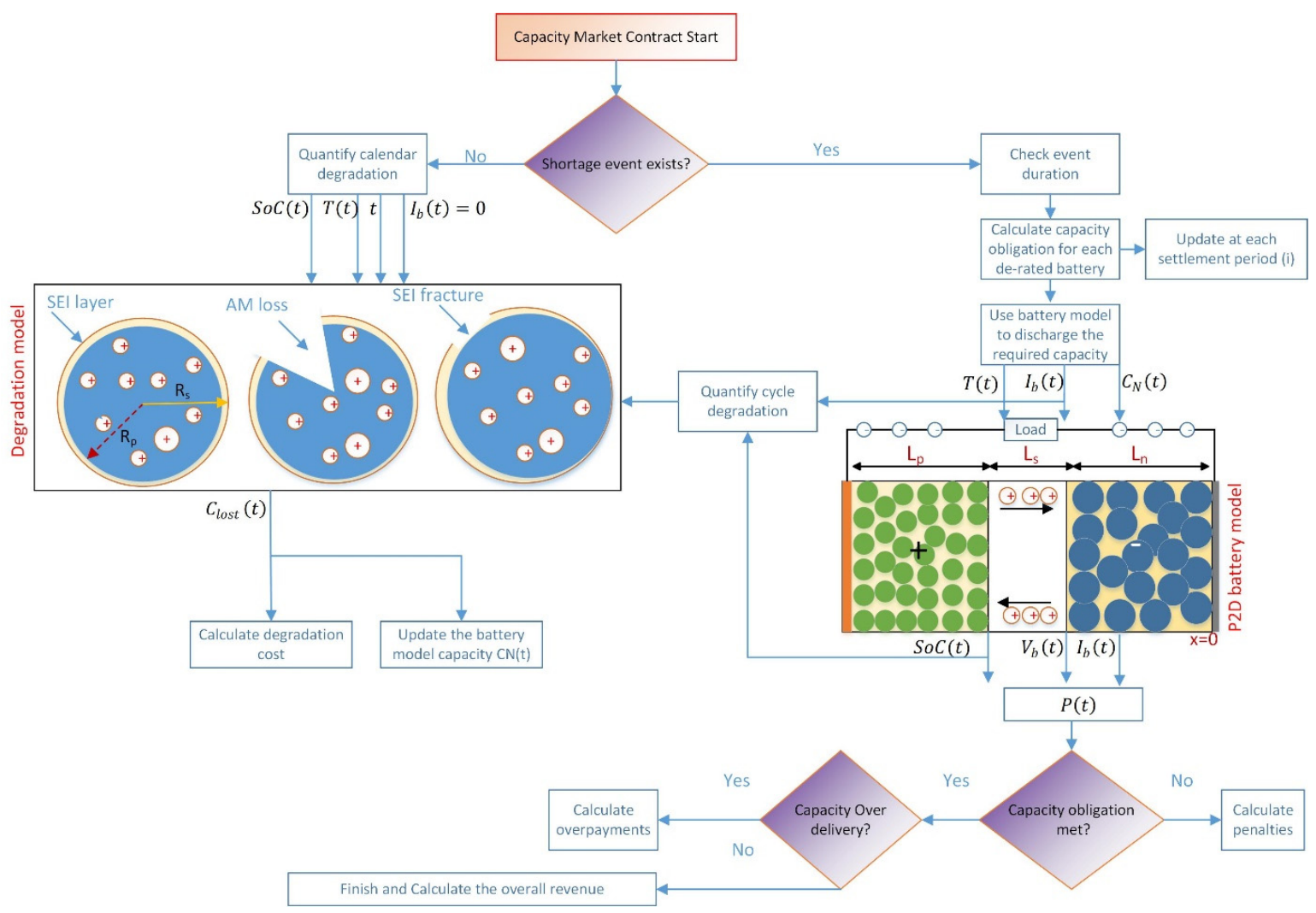

Figure 3. Revenue and degradation cost flow chart process in the capacity market.

Table 1. The battery capacity and the de-rating factors used in this study.

\begin{tabular}{ccc}
\hline Battery Energy Capacity (MWh) & $\begin{array}{c}\text { Generated Power } \\
\text { (MW) }\end{array}$ & $\begin{array}{c}\text { De-Rating } \\
\text { (h) }\end{array}$ \\
\hline 2 & 2 & 0.5 \\
2 & 2 & 1 \\
2 & 1 & 2 \\
2 & 0.5 & 4 \\
\hline
\end{tabular}

The total revenue of battery $R$ represents the revenue from the CM contract in addition to overpayments $R_{o v}$ minus potential penalties $p$, as given in Equation (1), where $C_{d e}$ is the de-rated capacity, $k_{d e}$ is the de-rating factor, $\lambda_{c l}$ is the $\mathrm{CM}$ auction clearing price, and $f$ is a factor used to reward slightly more payment in peak demand months:

$$
R=C_{d e} \times \lambda_{c l} \times f+R_{o v}-p
$$

The de-rated capacity $C_{d e}$ depends on the battery's output power, as in Equation (2), where $I_{b}(t)$ is the battery current, $V_{b}(t)$ is the battery voltage, and $N$ is the total number of battery cells.

$$
C_{d e}=I_{b}(t) \times V_{b}(t) \times N \times k_{d e}
$$


The capacity obligation $C_{0}$ is calculated at each settlement period (i), as in Equations (3) and (4), where $D_{p}$ is the peak electricity demand during the SE $D_{p}^{s e}$ divided by the total CM contracted capacity through the $\mathrm{CM}$ auction $C_{a u c}$, and $C_{b}$ is the capacity offered by the battery to other grid services.

$$
\begin{gathered}
C_{o}(i)=\sum_{i=1}^{n}\left(C_{d e} \times D_{p}(i)\right)-C_{b}(i) \\
D_{p}(i)=\frac{D_{p(i)}^{s e}}{C_{a u c}}
\end{gathered}
$$

The penalties and the overpayments are obtained by calculating the amount of undelivered or overdelivered capacity over the CM contract at each settlement period, as in Equations (5) and (6):

$$
\begin{gathered}
p=\sum_{i=1}^{t} C_{u n(i)} \times \lambda_{c l} \\
R_{o v}=\sum_{i=1}^{t} C_{o v(i)} \times \lambda_{c l}
\end{gathered}
$$

By multiplying the lost battery capacity $C_{\text {lost }}(t)$, which is obtained from the battery degradation model by a degradation price $\lambda_{\text {degr }}$, the total energy degradation cost $E_{\text {lost }}$ can be roughly estimated, as in Equation (7):

$$
E_{\text {lost }}=C_{\text {lost }}(t) \times \lambda_{\text {degr }} \times N
$$

\subsection{Battery Cycling Profile}

The battery cycles in the $\mathrm{CM}$ are calculated according to the SE period. The expected number of these SEs is based on the loss of the lead expectation (LOLE) reliability metric [58]. Since accurately predicting the LOLE is difficult, as it is a function of complex processes such as generator availability, blackouts, and environmental factors, many studies deem LOLE to be unreliable [59,60]. In the presence of a high share of RESs, it is found that the LOLE can reach $62 \mathrm{~h}$ per year [61]. Another study found that LOLE can reach $83 \mathrm{~h}$ per year, considering the current $\mathrm{CM}$ scarcity prices [62]. Therefore, by considering the difficulty in estimating realistic LOLE values and the previous studies, this work assumes that the total number of SEs of different durations is 20 in the first year of the CM's contract, while increasing to 90 in the following year (from months 13 to 24), as shown in Figure 4. This distribution of SEs considers the electricity peak demand periods in most parts of Europe [63]. Furthermore, the distribution reflects the probability of the duration of SEs; for instance, events lasting $1 \mathrm{~h}$ and $2 \mathrm{~h}$ are more probable than events lasting $4 \mathrm{~h}$ [64].

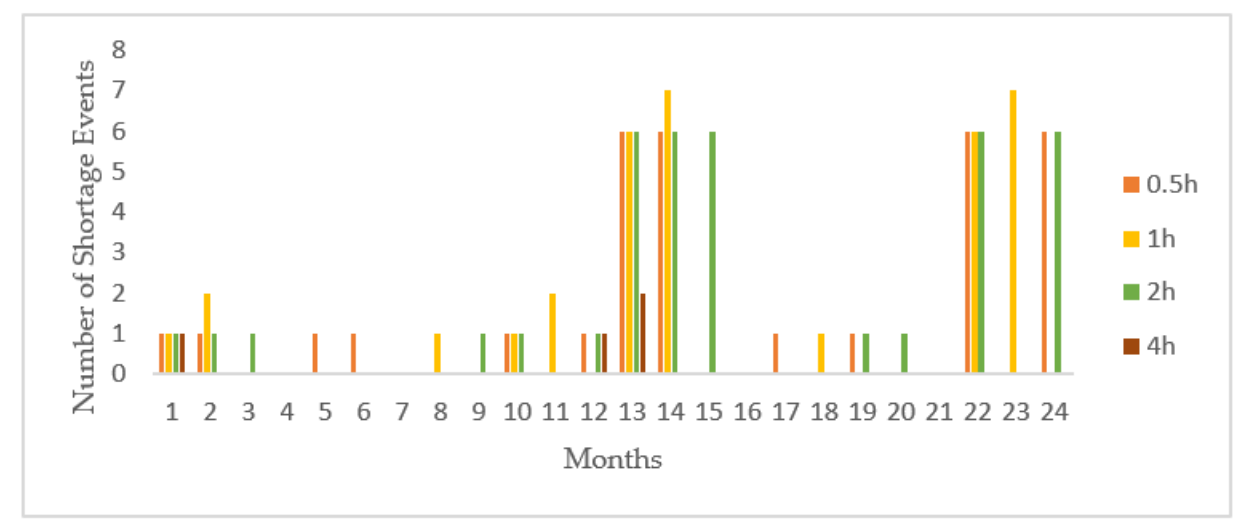

Figure 4. Battery cycling profile according to the number of expected shortage events in the capacity market. 


\subsection{Battery and Degradation Models}

\subsubsection{Battery Model}

The electrochemical battery cell model is shown in Figure 1 and based on the seminal work by Newman et al. [65]. The input to the model is the load current, material properties, geometry design parameters, and the operating temperature. The output is the cell voltage and the SoC. The model parameters values used in this study are given in Appendix A. The five model states are the lithium concentration in the solid $\left(c_{s}\right)$ and electrolyte $\left(c_{e}\right)$ phases, the electric potential in the solid $\left(\phi_{s}\right)$ and electrolyte $\left(\phi_{e}\right)$ phases, along with the rate of lithium movement between the phases $\left(j^{L i}\right)$ [66]. These variables can be found by solving five coupled differential equations, along with their boundary conditions, as described below.

The mass conservation of lithium (assuming the concentration of lithium within the particles is spherically symmetric) in the solid phase can be described using Fick's second law in Equation (8), where $\left(D_{s}\right)$ is the solid phase diffusion constant and $(r)$ is the radial (pseudo) dimension. The first boundary condition of Equation (8) is given by Equation (9), indicating that there is no diffusion in the center of the particle. The second boundary condition is given by Equation (10), indicating that the transfer of charges occur at the outer boundary of the particle, where $\left(a_{s}\right)$ is the specific interfacial area between the solid and the electrolyte, $\left(R_{p}\right)$ is the particle radius, and $(F)$ is Faraday's constant:

$$
\begin{gathered}
\frac{\partial c_{s}}{\partial t}=\frac{D_{s}}{r^{2}} \frac{\partial}{\partial r}\left(r^{2} \frac{\partial c_{s}}{\partial r}\right) \\
\left.\frac{\partial c_{s}}{\partial r}\right|_{r=0}=0 \\
-\left.D_{s} \frac{\partial c_{s}}{\partial r}\right|_{r=R_{p}}=\frac{j^{L i}}{a_{s} F}
\end{gathered}
$$

The lithium concentration in the electrolyte phase is the result of diffusion (first term) and due to charge transfer between the solid and the electrolyte (second term), as in Equation (11), where $\left(\varepsilon_{e}\right)$ is the porosity and $\left(t_{0}^{+}\right)$is the transference number of the cation with respect to the solvent. Since there must be no electrolyte flux at the cell boundaries, the boundary conditions of Equation (11) are given in Equation (12):

$$
\begin{gathered}
\frac{\partial\left(\varepsilon_{e} c_{e}\right)}{\partial t}=\frac{\partial}{\partial x}\left(D_{e}^{e f f} \frac{\partial}{\partial x} c_{e}\right)+\frac{1-t_{0}^{+}}{F} j^{L i} \\
\left.\frac{\partial c_{e}}{\partial x}\right|_{x=L_{n}}=\left.\frac{\partial c_{e}}{\partial x}\right|_{x=L_{p}}=0
\end{gathered}
$$

The solid-phase charge conservation follows Ohm's law, since $\left(\phi_{s}\right)$ depends on the current passing through the solid, as in Equation (13), where $\left(\sigma^{\text {eff }}\right)$ is the effective conductivity. The current only flows at the collector-solid interface, as in the boundary conditions in Equation (14), where $(A)$ is the electrode area:

$$
\begin{gathered}
\frac{\partial}{\partial x}\left(\sigma^{e f f} \frac{\partial}{\partial x} \phi_{s}\right)=j^{L i} \\
-\left.\sigma^{e f f} \frac{\partial \phi_{s}}{\partial x}\right|_{x=0}=-\left.\sigma^{e f f} \frac{\partial \phi_{s}}{\partial x}\right|_{x=L_{T}}=\frac{I}{A} \\
-\left.\sigma^{e f f} \frac{\partial \phi_{s}}{\partial x}\right|_{x=L_{n}}=-\left.\sigma^{e f f} \frac{\partial \phi_{s}}{\partial x}\right|_{x=L_{p}}=0
\end{gathered}
$$

The electrolyte-phase charge conservation follows Ohm's law in a liquid electrolyte (first term) and the local concentration of lithium (second term), as in Equation (15), where ( $\kappa^{\text {eff }}$ ) is the effective 
conductivity of the electrolyte. At the boundary of the electrode-current collector interphase, the ionic current must be zero, as in Equation (16), where:

$$
\begin{gathered}
\frac{\partial}{\partial x}\left(\kappa^{e f f} \frac{\partial}{\partial x} \phi_{e}\right)+\frac{\partial}{\partial x}\left(\kappa_{D}^{e f f} \frac{\partial}{\partial x} \ln c_{e}\right)=j^{L i} \\
\left.\frac{\partial \phi_{e}}{\partial x}\right|_{x=0}=\left.\frac{\partial \phi_{e}}{\partial x}\right|_{x=L_{T}}=0
\end{gathered}
$$

Equations (8)-(16) are coupled through the Butler-Volmer equation in Equation (17), where $\left(i_{o}\right)$ is the exchange current density; $(R)$ is the universal gas constant; $(T)$ is the temperature; $\left(\alpha_{a}, \alpha_{c}\right)$ are anode and cathode symmetry factors, respectively; and $(\eta)$ is the reaction overpotential.

$$
j^{L i}=a_{s} i_{o}\left\{\exp \left(\frac{\alpha_{a} F}{R T} \eta\right)-\exp \left(-\frac{\alpha_{c} F}{R T} \eta\right)\right\}
$$

After solving the above equations, the cell voltage and SoC are given in Equations (18) and (19):

$$
\begin{gathered}
V_{b}(t)=\phi_{s}\left(L_{T}, t\right)-\phi_{s}(0, t) \\
x=\mathrm{SoC}=\frac{c_{s, a v g}^{\text {pos }}}{c_{s, \text { max }}^{\text {pos }}}, y=\frac{c_{s, \text { neg }}}{c_{s, \text { neg }}^{\text {neg }}}
\end{gathered}
$$

\subsubsection{Degradation Model}

Several degradation mechanisms for LIBs are presented in the literature and various models are reported to describe these mechanisms, with more than one model often used to describe a single mechanism [36]. Here, three dominant aging mechanisms are included and are shown in Figure 1: SEI layer growth, active material (AM) loss, and SEI layer fracture. For a complete derivation of these models, please refer to [67-69]. The degradation model used in this work is dependent on the P2D battery model described in [70].

The total degradation equation that represents all the three mechanisms is given in Equation (20). The SEI layer growth $\left(Q_{S E I}\right)$ is directly proportional to the side reaction current density $i_{s}$. The governing equations related to this are given in Equations (21)-(24). During the charge-discharge process, the mechanical stress generated inside the active material could result in particle fracture, which in turns may isolate the active material. As such, the amount of lithium is reduced, leading to capacity loss $\left(Q_{A M}\right)$, as given in Equation (25). SEI fracture is observed in [71], where the SEI layer experiences tensile stress as the active material expands. This results in the SEI layer stretching and cracking $\left(Q_{S E I, c r a c k}\right)$, which exacerbates the battery cell's harmful side reaction. The governing equations of $\left(Q_{S E I, \text { crack }}\right)$ are given in Equations (26) and(27). All the parameters used in this degradation model are given in Appendix B.

$$
\begin{gathered}
C_{\text {lost }}(t)=Q_{S E I}+Q_{A M}+Q_{S E I, \text { crack }} \\
Q_{S E I}=\int_{0}^{t} i_{s}(t) d t=\int_{0}^{t} \frac{k_{S E I} \exp \left(\frac{-E_{S E I}}{R T}\right)}{2(1+\lambda \theta) \sqrt{t}} \\
\theta=\exp \left[\frac{F}{R T}\left(\eta_{k}+U_{n}^{O C P}-U_{s}^{O C P}\right)\right] \\
\eta_{k}=\frac{2 R T}{F} \ln \left(\xi+\sqrt{\xi^{2}+1}\right) \\
\xi=\frac{R_{p} \mathrm{I}_{b}(\mathrm{t})}{6 \varepsilon_{A M, 0} i_{0} V}
\end{gathered}
$$




$$
\begin{gathered}
Q_{A M}=\int_{0}^{t} \operatorname{SoC} d \varepsilon_{A M}=\int_{0}^{t} k_{A M} \exp \left(\frac{-E_{A M}}{R T}\right) \operatorname{SoC}\left|I_{b}(t)\right| d t \\
Q_{S E I, \text { crack }}=\sum_{k=1}^{N c} Q_{S E I, \text { crack }}=k_{S E I, \text { crack }} \sum n_{k}\left(\sigma_{k}\right)\left(\frac{\sigma_{k}}{\sigma_{\text {Yield }}}\right)^{1 / m} \\
\sigma_{k}=\frac{\sigma_{\text {max }, k}-\sigma_{\text {min }, k}}{2}
\end{gathered}
$$

\section{Results}

\subsection{Accuracy of Battery and Degradation Models}

The output voltage against the battery capacity is shown in Figure $5 a, b$ for different current rates and temperatures during discharge. The model results are in good agreement with the experimental data presented in [72] for the same 53 Ah nickel (N) manganese (M) cobalt (C) LIB cell. In Figure 5a, as expected, the higher the current rating, the lower the battery capacity, which is a common feature for many other LIB types [73]. One reason for the lower capacity retention at higher current rates is due to the induced overpotential, which reduces the cell capacity and the cell voltage, especially at higher DoD [74].The battery capacity at the $4 \mathrm{C}$ rate, for instance, is $49.7 \mathrm{Ah}$ in the first cycles, meaning its effective capacity is $93.7 \%$ or lower compared to $56 \mathrm{Ah}$ at the $0.25 \mathrm{C}$ rate.

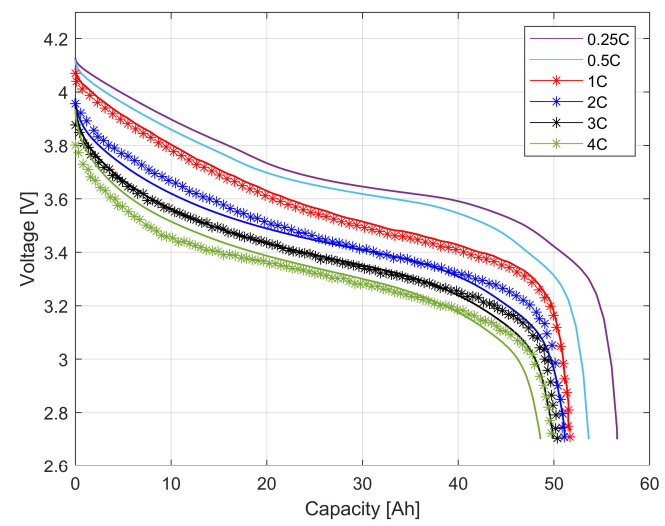

(a)

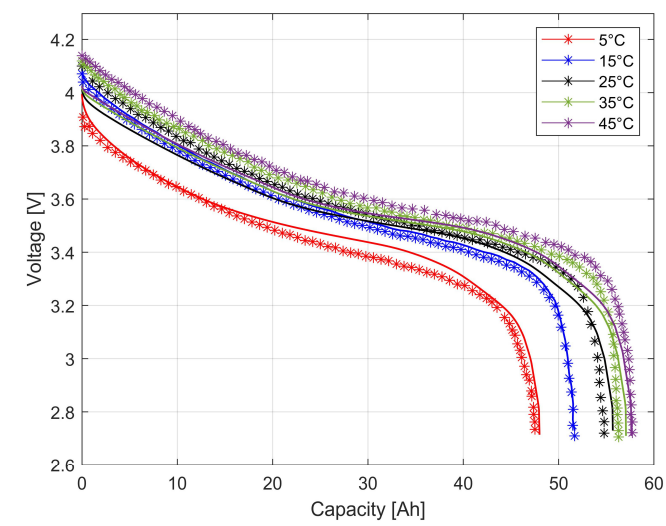

(b)

Figure 5. Battery model results (lines) with experimental data (markers) during discharge based on [72] (a): for different discharge-rates and $\mathrm{T}=15^{\circ} \mathrm{C} ;(\mathbf{b})$ for different temperatures at 1 discharge rate.

Figure $5 \mathrm{~b}$ shows the battery capacity and voltage for different temperatures at the $1 \mathrm{C}$ rate plotted against their experimental data. It can be seen that at lower temperatures, such as $5{ }^{\circ} \mathrm{C}$, the battery capacity predicted by the model is $48 \mathrm{Ah}$ compared to the $47.5 \mathrm{Ah}$ value obtained experimentally. This suggests that without any degradation, this LIB cell capacity is $89.6 \%$ at $5{ }^{\circ} \mathrm{C}$ because of the increased battery resistance at lower temperatures [75]. The model's average root mean square error is $1.1 \%$. It should be noted that the cycle life performance of the NMC battery chemistry is highly dependent on different temperatures and electrochemical conditions, which may affect the total capacity presented in this study. For further information on the different NMC compositions and their capacity retention levels under different operation conditions, please see [76].

The LIB cell degradation as predicted by Equation (20) and the corresponding experimental data are presented in Figure $6 \mathrm{a}$ for calendar degradation and Figure $6 \mathrm{~b}$ for cycle degradation. The calendar experimental data were taken from [77] and the cycle experimental data were taken from [78]. The model results show good agreement with experiment data, except for the results at $45{ }^{\circ} \mathrm{C}$ at $100 \%$ SoC. In Figure 6a, high capacity loss is evident at higher temperatures and SoCs, and vice versa. 
For instance, at $5{ }^{\circ} \mathrm{C}$, the LIB's state of health is over $96 \%$ after 500 days, indicating that there is minimal capacity loss.

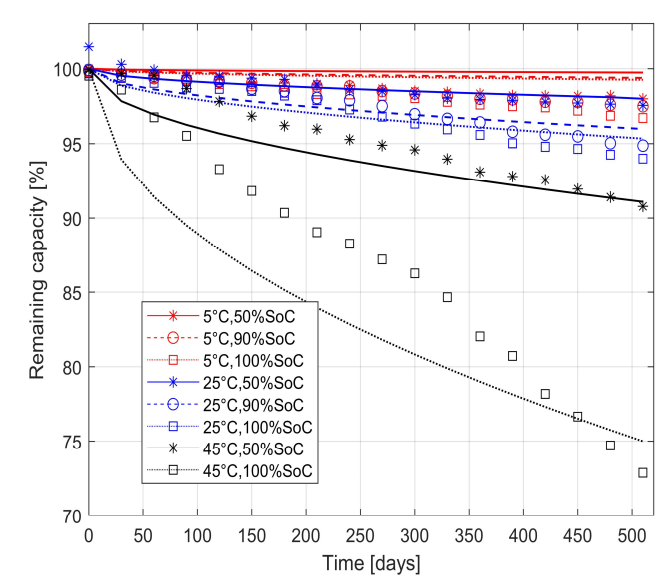

(a)

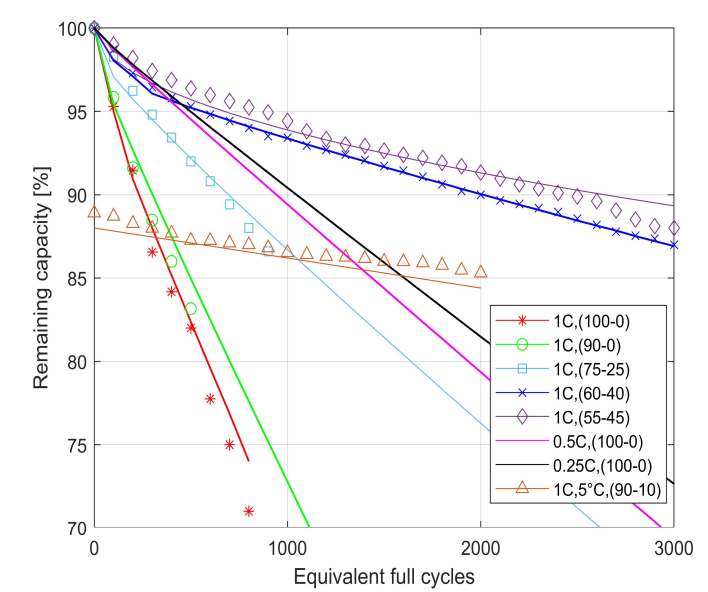

(b)

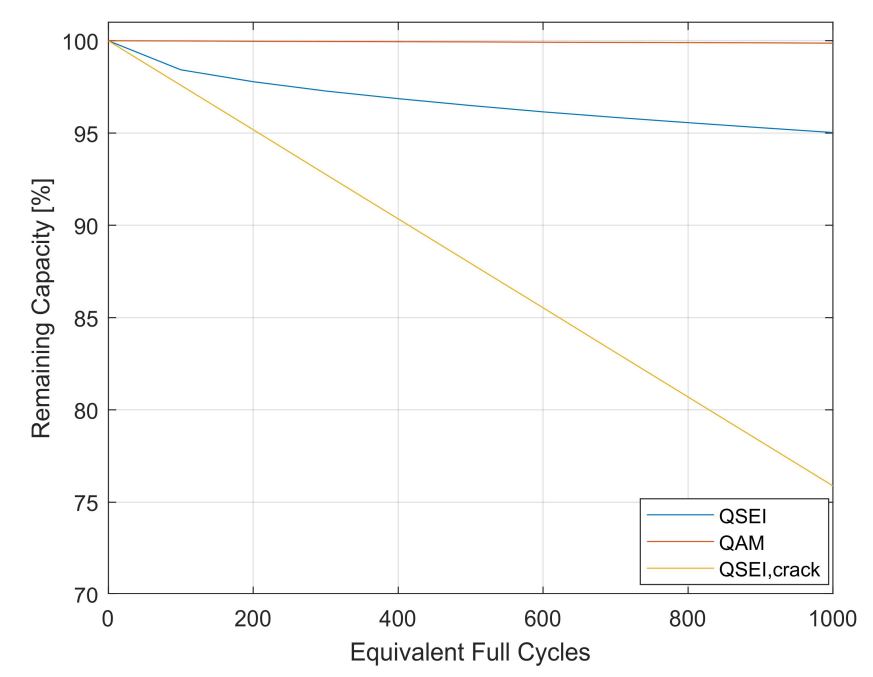

(c)

Figure 6. Battery degradation model results (lines) with their experimental data (markers) (a): calendar aging results with different temperatures and states of charge with experimental data taken from [77]; (b) cycle aging results with different depth of discharge ranges and C-rates at $\mathrm{T}=35^{\circ} \mathrm{C}$ with experimental data taken from [78], except for the $1 \mathrm{C}$ result at $5{ }^{\circ} \mathrm{C}(90-10)$ taken from [77]; (c) detailed version of 1C (100-0) degradation based on the physics-based degradation model mechanisms.

Figure $6 \mathrm{~b}$ shows the cycling results for different $\mathrm{C}$-rates at the same temperature of $35^{\circ} \mathrm{C}$, except for one result at $5{ }^{\circ} \mathrm{C}$. The results indicated that the higher the DoD, the higher the expected capacity loss at the same C-rate. Moreover, it can be seen that the cycling result at $5{ }^{\circ} \mathrm{C}$ is as expected based on the battery model results obtained in Figure 5b, in which the battery's state of health is $89 \%$ without any cycling, reaching $85 \%$ after 2000 cycles. This mitigates the limitations of other models, which are unable to show that calendar degradation is minimal at lower temperatures, while it is maximal when cycling at the same lower temperatures [48]. This is important in applications where calendar and cycle degradation quantification are needed, such as in the CM. In Figure $6 c$, a magnified version of the $1 \mathrm{C}$ rate $(100 \% \mathrm{DoD})$ is depicted to relate it to the three degradation mechanisms predicted using Equations (21), (25), and (26). It can be seen that at higher DoD levels, the $Q_{S E I, c r a c k}$ is in high agreement with [70]. 


\subsection{Revenue and Degradation Costs in the Capacity Market}

The collected revenues over a 12 months CM contract and any incurred degradation costs are depicted in Figures 7 and 8 for the four de-rated batteries in different conditions.
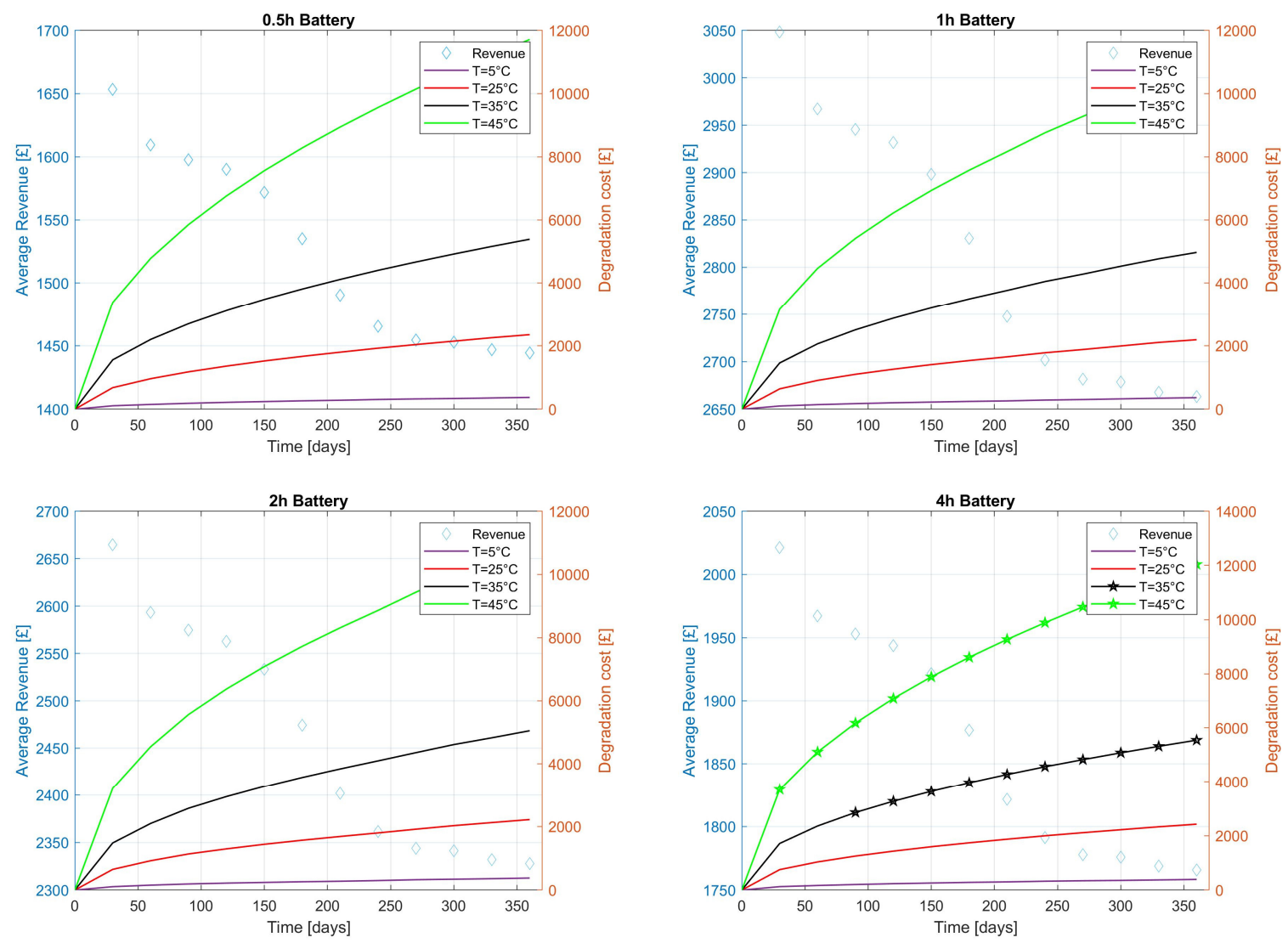

Figure 7. Revenue and degradation costs for four de-rated batteries $(0.5 \mathrm{~h}-4 \mathrm{~h})$ for a one-year capacity market contract with different charge states and $\mathrm{T}=25^{\circ} \mathrm{C}$.

In Figure 7 , the batteries were kept at room temperature $\left(25^{\circ} \mathrm{C}\right)$ and the SoC was varied. This was to account for a real case scenario, whereby the battery could be at a different SoC level in a thermally controlled environment until it is ready to respond to SEs. First, it can be seen that the $1 \mathrm{~h}$ de-rated battery has the highest revenue compared to the others due to the relatively high $k_{d e}$ compared to its $C_{0}$. The modeling results are confirmed, with many battery asset owners opting for $1 \mathrm{~h}$ de-rating factors in the latest CM auction [79]. Second, the degradation cost is lower at low SoC levels, as the calendar degradation is generally low. Third, compared with the same cases presented in [48], the physics-based degradation model predicts lower capacity losses under the same conditions. Therefore, it offers the opportunity for more overpayment, represented by Equation (6), as well as lowers the exposure to penalties (Equation (5)) for the $4 \mathrm{~h}$ de-rated battery. As such, the total collected revenue per CM contract is higher compared to the results presented in [48].

In Figure 8, the impact of the temperature change on the revenue is huge, necessitating a battery thermal management system to control the temperature at lower temperatures. However, when discharge occurs during SEs, it is necessary to increase the battery's temperature to respond effectively and avoid penalties. Since the cycling here is low during the first 12 months of the CM contract, as shown in Figure 4, the average revenue stays the same compared to Figure 7. 

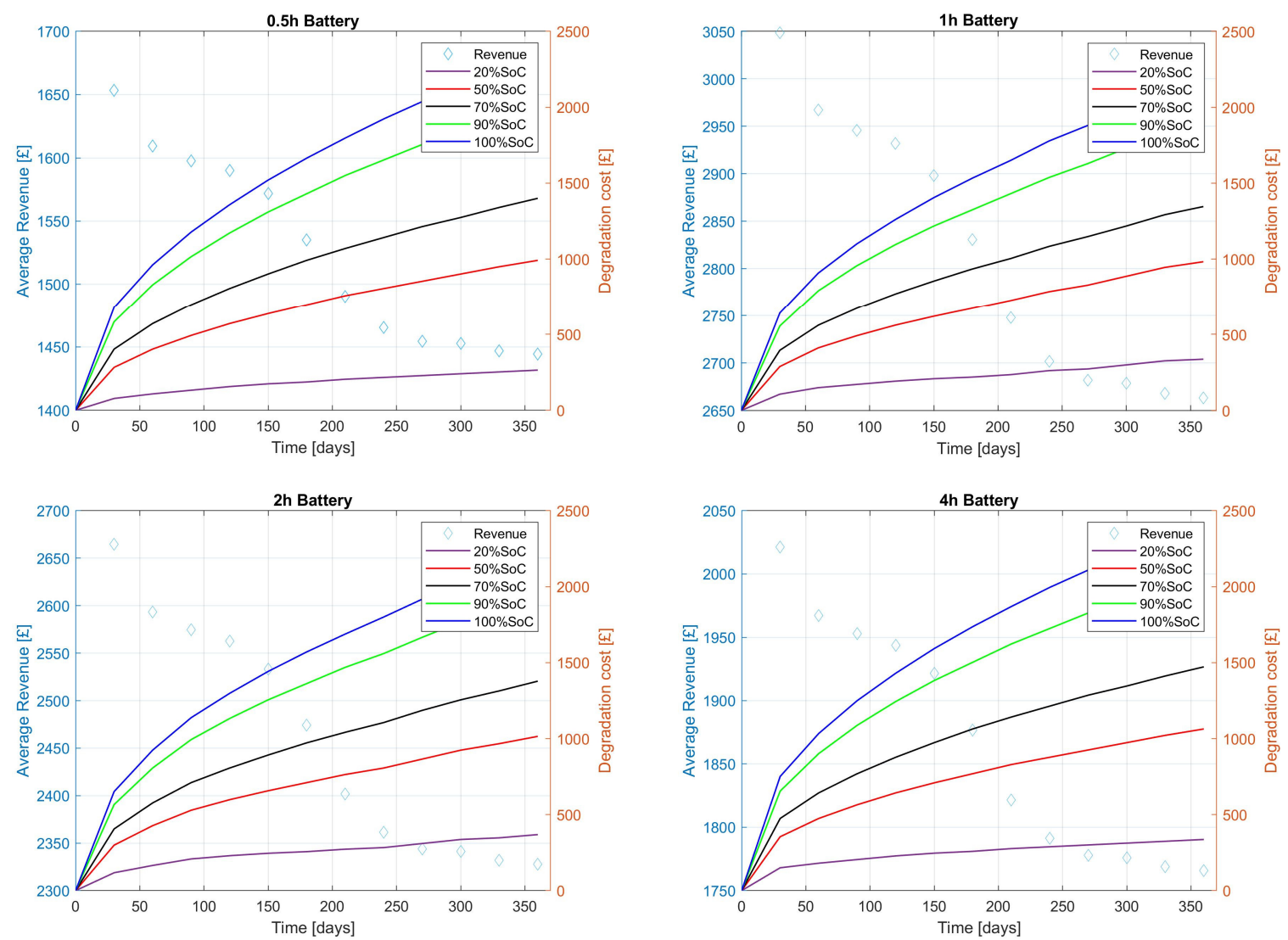

Figure 8. Revenue and degradation costs for four de-rated batteries ( $0.5 \mathrm{~h}-4 \mathrm{~h})$ for a one-year capacity market contract at different temperatures and at $100 \%$ state of charge.

Table 2 summarizes the accuracy of different degradation models, which have been used in the same CM application to predict the degradation cost. These are the empirical and semiempirical models reported in earlier study [48] and the physics-based degradation model used in this study. The physics-based degradation model is more accurate than the other two in predicting calendar and cycle degradation under different operating conditions. This is due to the feedback mechanism, which uses an accurate pseudo 2-dimensional (P2D) battery cell model, in which most of the parameters used account for the temperature- $C$ rate change, as given in Appendix A. Additionally, although empirical and semiempirical modes that are tied to equivalent circuit models can be useful and computationally fast, the process of determining the parameter values in these models uses empirical system identification. Therefore, changing the operating conditions necessitates the use of a different fitting, which is a time-consuming and unreliable process.

Table 2. Calendar and cycle degradation model accuracy comparisons for different temperatures.

\begin{tabular}{|c|c|c|c|c|c|c|}
\hline \multirow{3}{*}{ Temperatures } & \multicolumn{6}{|c|}{ Degradation Model Type } \\
\hline & \multicolumn{2}{|c|}{ Empirical } & \multicolumn{2}{|c|}{ Semiempirical } & \multicolumn{2}{|c|}{ Physics } \\
\hline & Calendar & Cycle & Calendar & Cycle & Calendar & Cycle \\
\hline $\begin{array}{l}\text { Low temperatures } \\
\left.\text { (5 }{ }^{\circ} \mathrm{C} \text { onwards }\right)\end{array}$ & $\mathrm{A}$ & $\mathrm{U}$ & $\mathrm{O}$ & A & $\mathrm{A}$ & $\mathrm{A}$ \\
\hline $\begin{array}{l}\text { Medium temperatures } \\
\left(25^{\circ} \mathrm{C} \text { onwards }\right)\end{array}$ & $\mathrm{A}$ & A & $\mathrm{A}$ & A & $\mathrm{A}$ & A \\
\hline $\begin{array}{l}\text { High temperatures } \\
\left(45^{\circ} \mathrm{C} \text { onwards }\right)\end{array}$ & $\mathrm{A}$ & $\mathrm{E}$ & $\mathrm{A}$ & A & $\mathrm{A}$ & A \\
\hline
\end{tabular}

A: accurate; U: underestimate degradation; O: overestimate degradation; E: extrapolation by Arrhenius equation. 
In Table 3 , the profit (revenue minus degradation cost) for the $1 \mathrm{~h}$ de-rated battery is calculated using the three different degradation model approaches (empirical, semiempirical, and physics). By using a physics-based degradation model when accounting for the degradation cost, the profit can be increased by $59.6 \%$ and $75.5 \%$ for $5{ }^{\circ} \mathrm{C}$ and $25^{\circ} \mathrm{C}$, respectively, when compared to both empirical and semiempirical models. This is due to the lower predicted degradation cost, which allows more overpayment to be collected. At higher temperatures such as $45^{\circ} \mathrm{C}$, the physics model predicts higher losses compared to the other two temperatures.

Table 3. Profit at the end of a 1-year capacity market contract fora battery with a de-rating factor of $1 \mathrm{~h}$ when using several degradation models.

\begin{tabular}{cccc}
\hline \multirow{2}{*}{ Temperatures } & \multicolumn{2}{c}{ Profit in $(£)$ When Degradation Cost is Calculated Using the Below Models } \\
\cline { 2 - 4 } & Empirical & Semiempirical & Physics \\
\hline $5{ }^{\circ} \mathrm{C}$ & 18,862 & $-16,962$ & 31,608 \\
$25^{\circ} \mathrm{C}$ & 4716 & 12,409 & 16,417 \\
$45^{\circ} \mathrm{C}$ & $-52,580$ & $-22,054$ & $-56,284$ \\
\hline
\end{tabular}

\subsection{Sensitivity Analysis}

This section investigates the effects of changing important parameters on the profitability of the batteries participating in the $\mathrm{CM}$. This include changes to the $\mathrm{CM}$ clearance price, battery degradation cost, de-rating factors, and increased SEs as a result of a predicted increase in energy demand. It should be noted that all the sensitivity analysis results are conducted at a standard temperature of $25^{\circ} \mathrm{C}$, except for in Section 4.3.4, where the temperature was set to $5^{\circ} \mathrm{C}$ to study the effects of $\mathrm{CM}$ penalties.

\subsubsection{Capacity Market Price Change Effects}

The CM clearing price $\lambda_{c l}$ is an important parameter that can be changed with different CM auction results. As such, $\lambda_{c l}$ has been changed twice to reflect the maximum and minimum auction prices obtained in the UK's CM auctions from the start of the CM until now. The original $\lambda_{c l}=£ 19.4 / \mathrm{kW} /$ year values were changed to $\lambda_{c l}=£ 27.5 / \mathrm{kW} /$ year and $\lambda_{c l}=£ 6 / \mathrm{kW} /$ year $[80,81]$. The profit (revenue-degradation cost) for a one-year CM contract is depicted in Figures 9 and 10, respectively, for the four de-rated batteries. In Figures 9 and 10, it can be seen that $\lambda_{c l}$ can hugely affect the batteries' profitability. In Figure 9, nearly all the four batteries are profitable at the end of the CM contract, as shown by an average increase of $167 \%$ compared to the normal case. In Figure 10, all the four batteries incurred huge losses due to low clearing prices and high degradation costs, as shown by a decrease of $170 \%$ compared to the normal case.

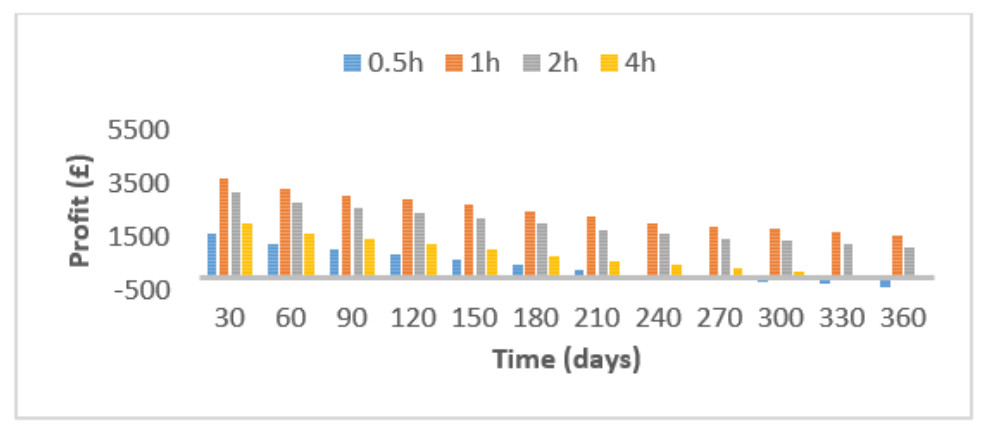

Figure 9. Profitability of the four de-rated batteries over 1 year when $\lambda_{c l}=£ 27.5 / \mathrm{kW} /$ year. 


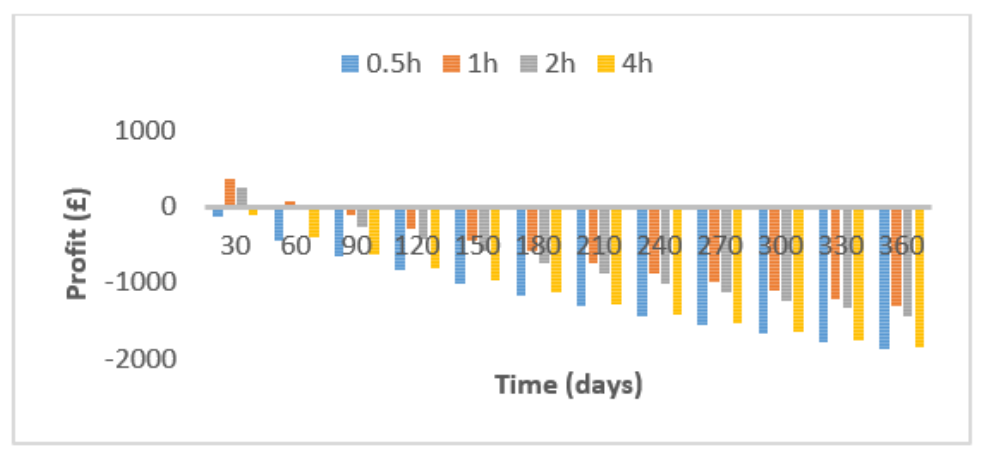

Figure 10. Profitability of the four de-rated batteries over 1 year when $\lambda_{c l}=£ 6 / \mathrm{kW} /$ year.

\subsubsection{Degradation Cost Effects}

The degradation cost is changed from $176 \$ / \mathrm{kWh}$ or $0.5 £ / \mathrm{Ah}$ to an optimistic $100 \$ / \mathrm{kWh}(0.29 £ / \mathrm{Ah})$, which is regarded as the ultimate goal for battery pack cost reduction in the future [82]. It can be seen in Figure 11 that all the batteries are profitable, with an average increase of nearly $50 \%$ over the standard case.

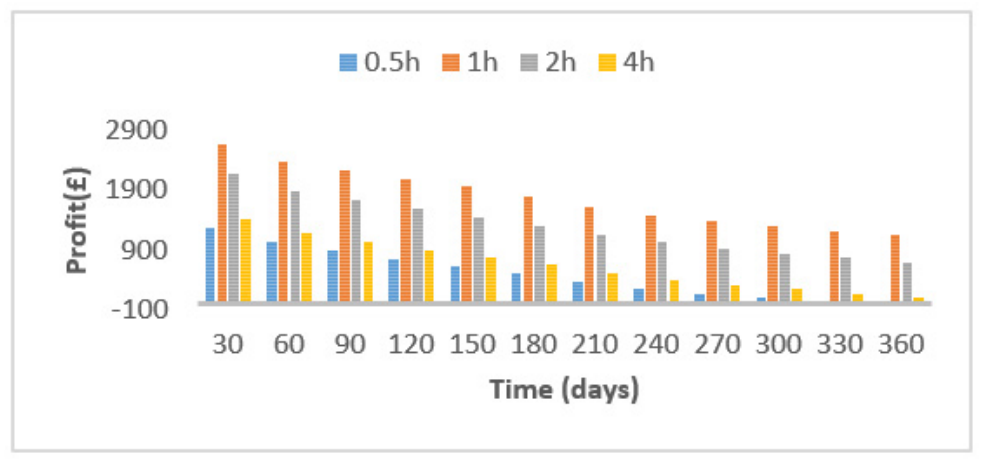

Figure 11. Profitability of the four de-rated batteries over 1 year when $\lambda_{\text {degr }}=\$ 100 / \mathrm{kWh}$.

\subsubsection{De-rating Factor Effects}

The presumed de-rating factors for all four batteries ( $0.5 \mathrm{~h}$ to $4 \mathrm{~h}$ ) are projected to decrease in the future to allow for new-generation entries in the $\mathrm{CM}$, as stated in [64]. Therefore, the de-rating factors have been changed accordingly to $17.80 \%$ for the $0.5 \mathrm{~h}$ battery, $36.44 \%$ for the $1 \mathrm{~h}$ battery, $64.79 \%$ for the $2 \mathrm{~h}$ battery, and $96.11 \%$ for the $4 \mathrm{~h}$ battery. As shown in Figure 12, the overall profitability decreased for the $0.5 \mathrm{~h}$ and $4 \mathrm{~h}$ batteries, meaning they are no longer profitable.

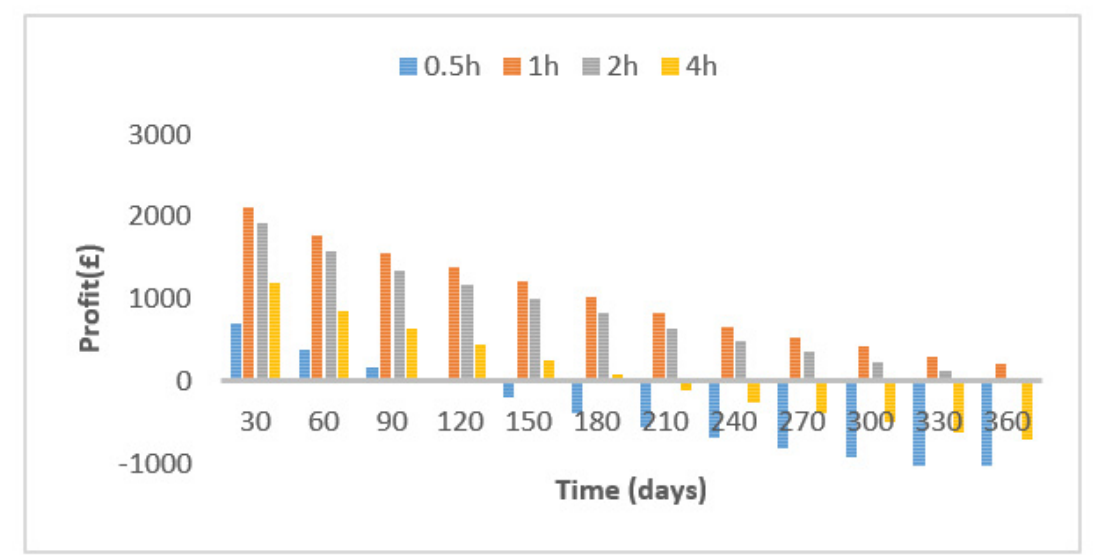

Figure 12. Profitability of the four de-rated batteries over 1 year with changes to the de-rating factors. 


\subsubsection{Increased Shortage Events in the CM}

In case of an expected increase in energy demand, the batteries in the $\mathrm{CM}$ are required to cycle more times per year, as shown in Figure 4, from month 13 to 24. In Figure 13, it can be seen that the $4 \mathrm{~h}$ battery is totally unprofitable due to the incurred penalties when cycling because of the high amount of capacity needed, which the battery cannot meet.

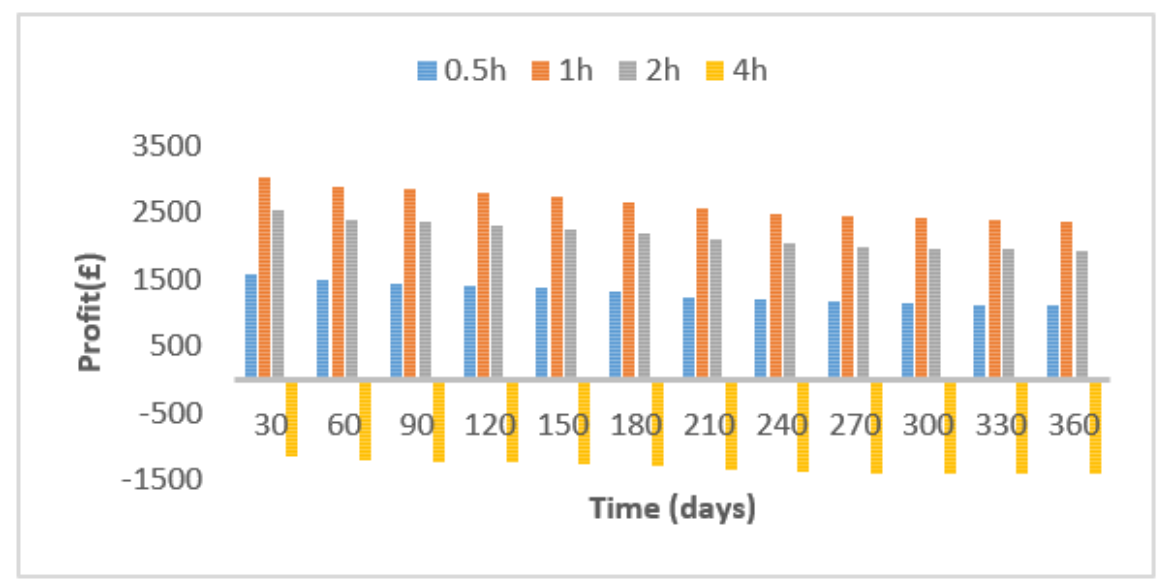

Figure 13. Profitability of the four de-rated batteries over 1 year with an increase in shortage events.

\section{Conclusions and Future Work}

This paper presented physics-based battery and degradation models that are used to inform a degradation cost analysis for lithium-ion batteries in the CM. The degradation model considers the SEI layer growth, active material loss, and SEI crack growth. The battery is utilized to obtain $0.5 \mathrm{~h}$, $1 \mathrm{~h}, 2 \mathrm{~h}$, and $4 \mathrm{~h} \mathrm{CM}$ de-rating factors. During a one-year CM contract, the battery experienced cycle and calendar degradation, resulting in a degradation cost. At the same time, depending on a battery's capacity obligation, a de-rated battery can generate revenue, overpayments, and penalties.

The results illustrate that the $1 \mathrm{~h}$ de-rated battery had the highest profit margin in the current $\mathrm{CM}$ design in all simulated scenarios. The results also show that batteries providing $\mathrm{CM}$ services should be stored at low temperatures, such as $5^{\circ} \mathrm{C}$. However, during shortage periods when the battery is delivering power, the temperature should be increased to $25^{\circ} \mathrm{C}$ to avoid penalties. Moreover, the physics-based degradation model accurately predicted calendar and cycle degradation for a wider range of temperature conditions compared to empirical and semiempirical models. Due to the lower predicted battery capacity loss, the batteries received more capacity overpayment, thus increasing the overall revenue. As such, the profit for the $1 \mathrm{~h}$ de-rated battery was increased by $59.6 \%$ and $75.5 \%$ for $5{ }^{\circ} \mathrm{C}$ and $25^{\circ} \mathrm{C}$, respectively, when compared to empirical and semiempirical models.

A sensitivity analysis for a range of parameters used in this study revealed that the CM profit can be affected in several ways. First, the profit for batteries is highly sensitive to the CM auction price. For instance, increasing the CM auction price by $30 \%$ can increase the profit by nearly $170 \%$ for the $1 \mathrm{~h}$ de-rated battery. Second, decreasing the degradation cost to the optimal battery pack price of $\$ 100 / \mathrm{kWh}$ can increase the profit by $50 \%$ for the $1 \mathrm{~h}$ de-rated battery. Third, decreasing the de-rating reduced the profitability for the $0.5 \mathrm{~h}$ and $4 \mathrm{~h}$ de-rated batteries. Fourth, increased cycling in the case of frequent SEs hugely decreased the profitability of the $4 \mathrm{~h}$ de-rated battery. Future work will include investigating how degradation of lithium plating can affect the overall CM design, considering different regions and energy storage technologies.

Author Contributions: Conceptualization, A.G. and M.A.-G.; methodology, A.G. and M.A.-G.; formal analysis, A.G., M.A.-G., M.S., N.D., and T.C.; investigation, A.G., M.A.-G., M.S., N.D., and T.C.; writing-original draft preparation, A.G.; writing-review and editing, A.G., T.C., M.A.-G., and N.D.; supervision, T.C., N.D., M.A.-G., and M.S. All authors have read and agreed to the published version of the manuscript. 
Funding: This research received no external funding.

Acknowledgments: Teesside University is gratefully acknowledged for fully supporting Ahmed's study. The authors would like also to thank the three anonymous reviewers for their contributions to improve the paper.

Conflicts of Interest: The authors declare no conflict of interest.

\section{Appendix A}

Table A1. Pseude2-dimensional Battery Model Parameters.

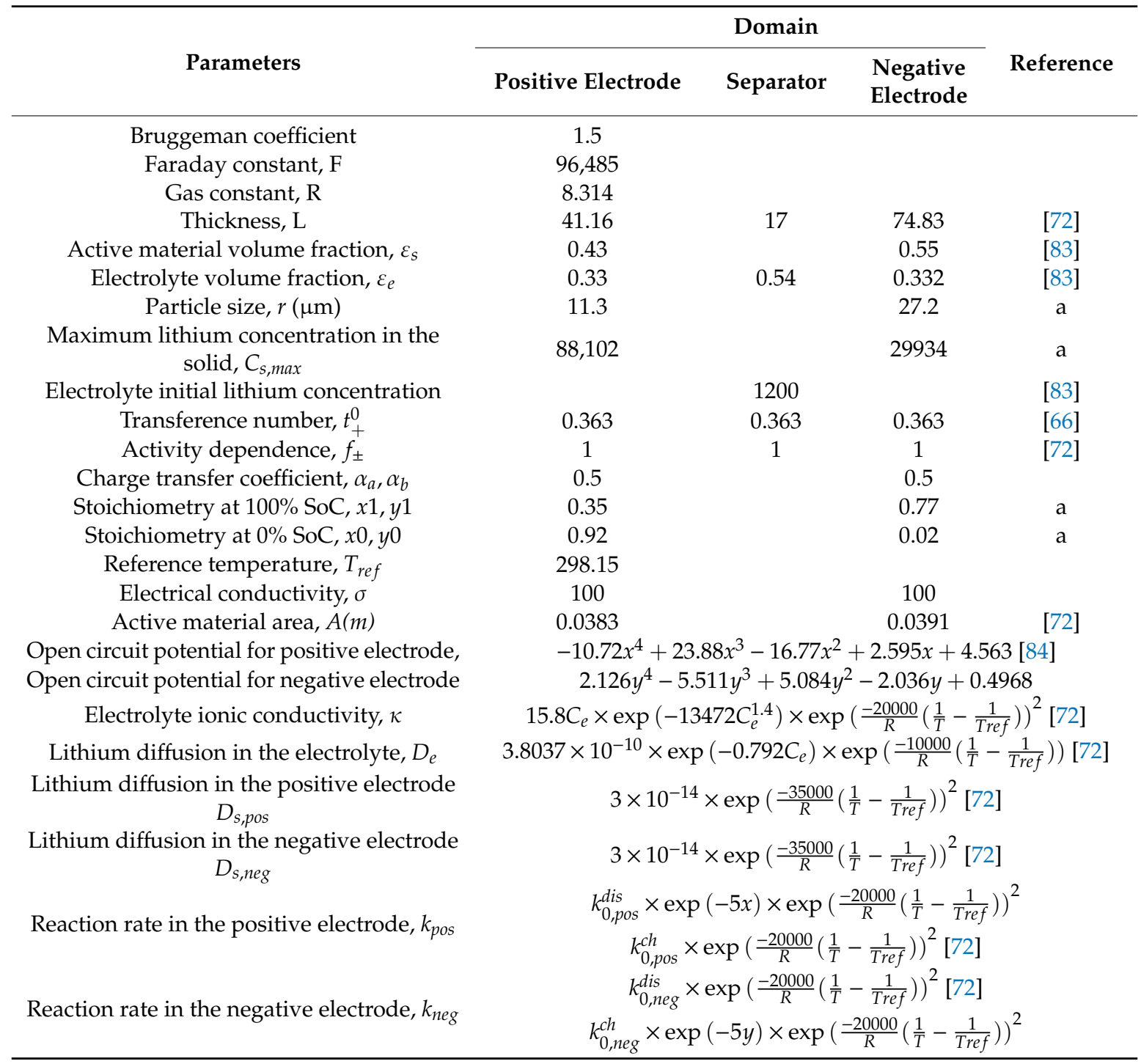

a: parameters estimation. 


\section{Appendix B}

Table A2. Degradation Model Parameters.

\begin{tabular}{|c|c|}
\hline Parameter & Value \\
\hline$k_{S E I}$ & $5.223 \times 10^{5}$ \\
\hline$k_{A M}$ & $7.88 \times 10^{-3}$ \\
\hline$k_{S E I, \text { crack }}$ & $2.22 \times 10^{-7}$ \\
\hline$E_{S E I}$ & 61,276 \\
\hline$E_{A M}$ & 39,600 \\
\hline$\lambda$ & 0.0148 \\
\hline $\mathrm{V}$ & $1.2 \times 10^{-5}$ \\
\hline$R_{p}$ & $9 \times 10^{-6}[68]$ \\
\hline$R_{S}$ & $9.2 \times 10^{-6}[68]$ \\
\hline$\varepsilon_{A M, 0}$ & 0.54 \\
\hline$i_{0}$ & 0.05 \\
\hline$\sigma_{\text {Yield }}$ & $8[70]$ \\
\hline $\mathrm{m}$ & 0.5 \\
\hline$E_{Y, S}$ & 0.42 \\
\hline$E_{Y, p}$ & 14.3 \\
\hline$v s$ & $0.2[70]$ \\
\hline$v p$ & $0.3[70]$ \\
\hline$\sigma_{k}$ & $\frac{\sigma_{\max , k}-\sigma_{\min , k}}{2}$ \\
\hline$\sigma_{\max , k}$ & $\frac{E_{Y, s}}{(1-2 v s)} b_{1}+\frac{E_{Y, s}}{R_{p}^{3}(1+v s)} b_{2}$ \\
\hline$\sigma_{\min , k}$ & $\frac{E_{Y, s}}{(1-2 v s)} b_{1}+\frac{E_{Y, s}}{R_{s}^{3}(1+v s)} b_{2}$ \\
\hline$b_{1}$ & $\frac{-2 E_{Y, p}(2 v s-1) \int_{0}^{R p} \Omega_{p}\left(c_{L I}(r, t)-c_{L I}(r, 0)\right) r^{2} d r}{E_{Y, p}\left(2 R_{p}^{3}+R_{s}^{3}-4 R_{p}^{3} v s+R_{s}^{3} v s\right)+E_{Y, s}\left(2 R_{s}^{3}-2 R_{p}^{3}+4 R_{p}^{3} v p-4 R_{s}^{3} v s\right)}[70]$ \\
\hline$b_{2}$ & $\frac{E_{Y_{, p}} R_{s}^{3}(v s+1) \int_{0}^{R p} \Omega_{p}\left(c_{L I}(r, t)-c_{L I}(r, 0)\right) r^{2} d r}{E_{Y, p}\left(2 R_{p}^{3}+R_{s}^{3}-4 R_{p}^{3} v s+R_{s}^{3} v s\right)+E_{Y, s}\left(2 R_{s}^{3}-2 R_{p}^{3}+4 R_{p}^{3} v p-4 R_{s}^{3} v s\right)}[70]$ \\
\hline
\end{tabular}

\section{References}

1. Cucchiella, F.; D'Adamo, I.; Gastaldi, M. Future Trajectories of Renewable Energy Consumption in the European Union. Resources 2018, 7, 10. [CrossRef]

2. British Petroleum. BP Statistical Review of World Energy; British Petroleum: London, UK, 2019; Available online: https:/www.bp.com/content/dam/bp/business-sites/en/global/corporate/pdfs/energy-economics/ statistical-review/bp-stats-review-2019-renewable-energy.pdf (accessed on 16 January 2020).

3. Kumar, J.; Parthasarathy, C.; Västi, M.; Laaksonen, H.; Shafie-Khah, M.; Kauhaniemi, K. Sizing and Allocation of Battery Energy Storage Systems in Åland Islands for Large-Scale Integration of Renewables and Electric Ferry Charging Stations. Energies 2020, 13, 317. [CrossRef]

4. Khalili, S.; Rantanen, E.; Bogdanov, D.; Breyer, C. Global Transportation Demand Development with Impacts on the Energy Demand and Greenhouse Gas Emissions in a Climate-Constrained World. Energies 2019, 12, 3870. [CrossRef]

5. Lisin, E.; Strielkowski, W.; Chernova, V.; Fomina, A. Assessment of the Territorial Energy Security in the Context of Energy Systems Integration. Energies 2018, 11, 3284. [CrossRef]

6. Heylen, E.; Deconinck, G.; Van Hertem, D. Review and classification of reliability indicators for power systems with a high share of renewable energy sources. Renew. Sustain. Energy Rev. 2018, 97, 554-568. [CrossRef]

7. Short, M.; Crosbie, T.; Dawood, M.; Dawood, N. Load forecasting and dispatch optimisation for decentralised co-generation plant with dual energy storage. Appl. Energy 2017, 186, 304-320. [CrossRef]

8. Park, S.H.; Hussain, A.; Kim, H.M. Impact Analysis of Survivability-Oriented Demand Response on Islanded Operation of Networked Microgrids with High Penetration of Renewables. Energies 2019, 12, 452. [CrossRef]

9. Kong, Q.; Fowler, M.; Entchev, E.; Ribberink, H.; McCallum, R. The Role of Charging Infrastructure in Electric Vehicle Implementation within Smart Grids. Energies 2018, 11, 3362. [CrossRef] 
10. Strielkowski, W.; Streimikiene, D.; Fomina, A.; Semenova, E. Internet of Energy (IoE) and High-Renewables Electricity System Market Design. Energies 2019, 12, 4790. [CrossRef]

11. Tucki, K.; Orynycz, O.; Wasiak, A.; Świć, A.; Dybaś, W. Capacity Market Implementation in Poland: Analysis of a Survey on Consequences for the Electricity Market and for Energy Management. Energies 2019, 12, 839. [CrossRef]

12. Gerard, H.; Rivero Puente, E.I.; Six, D. Coordination between transmission and distribution system operators in the electricity sector: A conceptual framework. Util. Policy 2018, 50, 40-48. [CrossRef]

13. Albertus, P.; Manser, J.S.; Litzelman, S. Long-Duration Electricity Storage Applications, Economics, and Technologies. Joule 2020, 4, 21-32. [CrossRef]

14. Mastropietro, P.; Rodilla, P.; Batlle, C. De-rating of wind and solar resources in capacity mechanisms: A review of international experiences. Renew. Sustain. Energy Rev. 2019, 112, 253-262. [CrossRef]

15. Bublitz, A.; Keles, D.; Zimmermann, F.; Fraunholz, C.; Fichtner, W. A survey on electricity market design: Insights from theory and real-world implementations of capacity remuneration mechanisms. Energy Econ. 2019, 80, 1059-1078. [CrossRef]

16. Lee, A.; Vörös, M.; Dose, W.M.; Niklas, J.; Poluektov, O.; Schaller, R.D.; Iddir, H.; Maroni, V.A.; Lee, E.; Ingram, B.; et al. Photo-accelerated fast charging of lithium-ion batteries. Nat. Commun. 2019, 10, 4946. [CrossRef] [PubMed]

17. Sioshansi, R.; Madaeni, S.H.; Denholm, P. A Dynamic Programming Approach to Estimate the Capacity Value of Energy Storage. IEEE Trans. Power Syst. 2014, 29, 395-403. [CrossRef]

18. Khan, A.S.M.; Verzijlbergh, R.A.; Sakinci, O.C.; De Vries, L.J. How do demand response and electrical energy storage affect (the need for) a capacity market? Appl. Energy 2018, 214, 39-62. [CrossRef]

19. Staffell, I.; Rustomji, M. Maximising the value of electricity storage. J. Energy Storage 2016, 8, $212-225$. [CrossRef]

20. Teng, F.; Strbac, G. Business cases for energy storage with multiple service provision. J. Mod. Power Syst. Clean Energy 2016, 4, 615-625. [CrossRef]

21. Xu, B.; Oudalov, A.; Ulbig, A.; Andersson, G.; Kirschen, D.S. Modeling of Lithium-Ion Battery Degradation for Cell Life Assessment. IEEE Trans. Smart Grid 2018, 9, 1131-1140. [CrossRef]

22. Castagneto Gissey, G.; Dodds, P.E.; Radcliffe, J. Market and regulatory barriers to electrical energy storage innovation. Renew. Sustain. Energy Rev. 2018, 82, 781-790. [CrossRef]

23. Chen, H.; Baker, S.; Benner, S.; Berner, A.; Liu, J. PJM Integrates Energy Storage: Their Technologies and Wholesale Products. IEEE Power Energy Mag. 2017, 15, 59-67. [CrossRef]

24. Kumar, A.; Meena, N.K.; Singh, A.R.; Deng, Y.; He, X.; Bansal, R.C.; Kumar, P. Strategic integration of battery energy storage systems with the provision of distributed ancillary services in active distribution systems. Appl. Energy 2019, 253, 113503. [CrossRef]

25. Askeland, M.; Jaehnert, S.; Korpås, M. Equilibrium assessment of storage technologies in a power market with capacity remuneration. Sustain. Energy Technol. Assess. 2019, 31, 228-235. [CrossRef]

26. Haas, J.; Cebulla, F.; Nowak, W.; Rahmann, C.; Palma-Behnke, R. A multi-service approach for planning the optimal mix of energy storage technologies in a fully-renewable power supply. Energy Convers. Manag. 2018, 178, 355-368. [CrossRef]

27. Lorenzi, G.; da Silva Vieira, R.; Santos Silva, C.A.; Martin, A. Techno-economic analysis of utility-scale energy storage in island settings. J. Energy Storage 2019, 21, 691-705. [CrossRef]

28. Greenwood, D.M.; Lim, K.Y.; Patsios, C.; Lyons, P.F.; Lim, Y.S.; Taylor, P.C. Frequency response services designed for energy storage. Appl. Energy 2017, 203, 115-127. [CrossRef]

29. Denholm, P.; Nunemaker, J.; Gagnon, P.; Cole, W. The potential for battery energy storage to provide peaking capacity in the United States. Renew. Energy 2019, 151, 1269-1277. [CrossRef]

30. Andrenacci, N.; Chiodo, E.; Lauria, D.; Mottola, F. Life Cycle Estimation of Battery Energy Storage Systems for Primary Frequency Regulation. Energies 2018, 11, 3320. [CrossRef]

31. Martins, R.; Hesse, C.H.; Jungbauer, J.; Vorbuchner, T.; Musilek, P. Optimal Component Sizing for Peak Shaving in Battery Energy Storage System for Industrial Applications. Energies 2018, 11, 2048. [CrossRef]

32. Xu, B.; Zhao, J.; Zheng, T.; Litvinov, E.; Kirschen, D.S. Factoring the Cycle Aging Cost of Batteries Participating in Electricity Markets. IEEE Trans. Power Syst. 2018, 33, 2248-2259. [CrossRef]

33. Kies, A. Joint optimisation of arbitrage profits and battery life degradation for grid storage application of battery electric vehicles. J. Phys. Conf. Ser. 2018, 977, 012005. [CrossRef] 
34. Petit, M.; Prada, E.; Sauvant-Moynot, V. Development of an empirical aging model for Li-ion batteries and application to assess the impact of Vehicle-to-Grid strategies on battery lifetime. Appl. Energy 2016, 172, 398-407. [CrossRef]

35. Thompson, A.W. Economic implications of lithium ion battery degradation for Vehicle-to-Grid (V2X) services. J. Power Sources 2018, 396, 691-709. [CrossRef]

36. Reniers, J.M.; Mulder, G.; Howey, D.A. Review and Performance Comparison of Mechanical-Chemical Degradation Models for Lithium-Ion Batteries. J. Electrochem. Soc. 2019, 166, A3189-A3200. [CrossRef]

37. Maheshwari, A.; Paterakis, N.G.; Santarelli, M.; Gibescu, M. Optimizing the operation of energy storage using a non-linear lithium-ion battery degradation model. Appl. Energy 2020, 261, 114360. [CrossRef]

38. Dubarry, M.; Devie, A.; Stein, K.; Tun, M.; Matsuura, M.; Rocheleau, R. Battery Energy Storage System battery durability and reliability under electric utility grid operations: Analysis of 3 years of real usage. J. Power Sources 2017, 338, 65-73. [CrossRef]

39. Wankmüller, F.; Thimmapuram, P.R.; Gallagher, K.G.; Botterud, A. Impact of battery degradation on energy arbitrage revenue of grid-level energy storage. J. Energy Storage 2017, 10, 56-66. [CrossRef]

40. Purvins, A.; Sumner, M. Optimal management of stationary lithium-ion battery system in electricity distribution grids. J. Power Sources 2013, 242, 742-755. [CrossRef]

41. Pimm, A.J.; Palczewski, J.; Morris, R.; Cockerill, T.T.; Taylor, P.G. Community energy storage: A case study in the UK using a linear programming method. Energy Convers. Manag. 2020, 205, 112388. [CrossRef]

42. Dufo-López, R.; Bernal-Agustín, J.L. Techno-economic analysis of grid-connected battery storage. Energy Convers. Manag. 2015, 91, 394-404. [CrossRef]

43. Patsios, C.; Wu, B.; Chatzinikolaou, E.; Rogers, D.J.; Wade, N.; Brandon, N.P.; Taylor, P. An integrated approach for the analysis and control of grid connected energy storage systems. J. Energy Storage 2016, 5, 48-61. [CrossRef]

44. Weißhar, B.; Bessler, W.G. Model-based degradation assessment of lithium-ion batteries in a smart microgrid. In Proceedings of the 2015 International Conference on Smart Grid and Clean Energy Technologies (ICSGCE), Offenburg, Germany, 20-23 October 2015; pp. 134-138.

45. Reniers, J.M.; Mulder, G.; Ober-Blöbaum, S.; Howey, D.A. Improving optimal control of grid-connected lithium-ion batteries through more accurate battery and degradation modelling. J. Power Sources 2018, 379, 91-102. [CrossRef]

46. Birkl, C.R.; Roberts, M.R.; McTurk, E.; Bruce, P.G.; Howey, D.A. Degradation diagnostics for lithium ion cells. J. Power Sources 2017, 341, 373-386. [CrossRef]

47. Usera, I.; Rodilla, P.; Burger, S.; Herrero, I.; Batlle, C. The Regulatory Debate About Energy Storage Systems: State of the Art and Open Issues. IEEE Power Energy Mag. 2017, 15, 42-50. [CrossRef]

48. Gailani, A.; Al-Greer, M.; Short, M.; Crosbie, T. Degradation Cost Analysis of Li-Ion Batteries in the Capacity Market with Different Degradation Models. Electronics 2020, 9, 90. [CrossRef]

49. Cramton, P.; Ockenfels, A. Economics and design of capacity markets for the power sector. In Interdisziplinäre Aspekte der Energiewirtschaft; Springer: Berlin/Heidelberg, Germany, 2016; pp. 191-212.

50. Cramton, P.; Ockenfels, A.; Stoft, S. Capacity Market Fundamentals. Econ. Energy Environ. Policy $2013,2$. [CrossRef]

51. Ashokkumar Parmar, A.; Pranav B Darji, B. Capacity market functioning with renewable capacity integration and global practices. Electr. J. 2020, 33, 106708. [CrossRef]

52. Energy Emergencies Executive Committee (E3C). GB Power System Disruption on 9 August 2019; UK Government: London, UK, 2020. Available online: https://assets.publishing.service.gov.uk/government/ uploads/system/uploads/attachment_data/file/855767/e3c-gb-power-disruption-9-august-2019-finalreport.pdf (accessed on 3 February 2020).

53. Cramton, P. Electricity market design. Oxf. Rev. Econ. Policy 2017, 33, 589-612. [CrossRef]

54. Sioshansi, F.P. Competitive Electricity Markets: Design, Implementation, Performance; Elsevier: Amsterdam, The Netherlands, 2011.

55. Gailani, A.; Crosbie, T.; Al-Greer, M.; Short, M.; Dawood, N. On the Role of Regulatory Policy on the Business Case for Energy Storage in Both EU and UK Energy Systems: Barriers and Enablers. Energies 2020, 13, 1080. [CrossRef]

56. Fraunholz, C.; Keles, D.; Fichtner, W. On the Role of Electricity Storage in Capacity Remuneration Mechanisms; Karlsruhe Institute of Technology (KIT): Karlsruhe, Germany, 2019. 
57. National Grid. Capacity Market Registers; National Grid: London, UK, 2019; Available online: https: //www.emrdeliverybody.com/CM/Registers.aspx (accessed on 25 April 2019).

58. Slipac, G.; Zeljko, M.; Šljivac, D. Importance of Reliability Criterion in Power System Expansion Planning. Energies 2019, 12, 1714. [CrossRef]

59. Söder, L.; Tómasson, E.; Estanqueiro, A.; Flynn, D.; Hodge, B.M.; Kiviluoma, J.; Korpås, M.; Neau, E.; Couto, A.; Pudjianto, D.; et al. Review of wind generation within adequacy calculations and capacity markets for different power systems. Renew. Sustain. Energy Rev. 2020, 119, 109540. [CrossRef]

60. THEMA Consulting Group. Capacity Adequacy in the Nordic Electricity Market; Nordic Energy: Oslo, Norway, 2015; Available online: https://www.nordicenergy.org/wp-content/uploads/2015/08/capacity_adequacy_ THEMA_2015-1.pdf (accessed on 16 March 2020).

61. Bhagwat, P.C.; Iychettira, K.K.; Richstein, J.C.; Chappin, E.J.L.; De Vries, L.J. The effectiveness of capacity markets in the presence of a high portfolio share of renewable energy sources. Util. Policy 2017, 48, 76-91. [CrossRef]

62. Bhagwat, P.C.; Marcheselli, A.; Richstein, J.C.; Chappin, E.J.L.; De Vries, L.J. An analysis of a forward capacity market with long-term contracts. Energy Policy 2017, 111, 255-267. [CrossRef]

63. Gallo Cassarino, T.; Sharp, E.; Barrett, M. The impact of social and weather drivers on the historical electricity demand in Europe. Appl. Energy 2018, 229, 176-185. [CrossRef]

64. National Grid. Duration-Limited Storage De-Rating Factor Assessment-Final Report; National Grid: London, UK, 2017; Available online: https://www.emrdeliverybody.com/Lists/Latest\%20News/Attachments/ 150/Duration\%20Limited\%20Storage\%20De-Rating\%20Factor\%20Assessment\%20-\%20Final.pdf (accessed on 18 April 2019).

65. Doyle, M. Modeling of Galvanostatic Charge and Discharge of the Lithium/Polymer/Insertion Cell. J. Electrochem. Soc. 1993, 140, 1526. [CrossRef]

66. Plett, G.L. Battery Management Systems, Volume I: Battery Modeling; Artech House: Norwood, MA, USA, 2015.

67. Jin, X.; Vora, A.; Hoshing, V.; Saha, T.; Shaver, G.; García, R.E.; Wasynczuk, O.; Varigonda, S. Physically-based reduced-order capacity loss model for graphite anodes in Li-ion battery cells. J. Power Sources 2017, 342, 750-761. [CrossRef]

68. Laresgoiti, I.; Käbitz, S.; Ecker, M.; Sauer, D.U. Modeling mechanical degradation in lithium ion batteries during cycling: Solid electrolyte interphase fracture. J. Power Sources 2015, 300, 112-122. [CrossRef]

69. Prada, E.; Di Domenico, D.; Creff, Y.; Bernard, J.; Sauvant-Moynot, V.; Huet, F. A Simplified Electrochemical and Thermal Aging Model of LiFePO4-Graphite Li-ion Batteries: Power and Capacity Fade Simulations. J. Electrochem. Soc. 2013, 160, A616-A628. [CrossRef]

70. Jin, X.; Liu, C. Physics-based control-oriented reduced-order degradation model for $\mathrm{LiNiMnCoO}_{2}-\mathrm{Graphite}$ cell. Electrochim. Acta 2019, 312, 188-201. [CrossRef]

71. Zhang, H.L.; Li, F.; Liu, C.; Tan, J.; Cheng, H.M. New Insight into the Solid Electrolyte Interphase with Use of a Focused Ion Beam. J. Phys. Chem. B 2005, 109, 22205-22211. [CrossRef] [PubMed]

72. Hosseinzadeh, E.; Genieser, R.; Worwood, D.; Barai, A.; Marco, J.; Jennings, P. A systematic approach for electrochemical-thermal modelling of a large format lithium-ion battery for electric vehicle application. J. Power Sources 2018, 382, 77-94. [CrossRef]

73. Li, J.; Wang, D.; Pecht, M. An electrochemical model for high C-rate conditions in lithium-ion batteries. J. Power Sources 2019, 436, 226885. [CrossRef]

74. Kasnatscheew, J.; Rodehorst, U.; Streipert, B.; Wiemers-Meyer, S.; Jakelski, R.; Wagner, R.; Laskovic, I.C.; Winter, M. Learning from overpotentials in lithium ion batteries: A case study on the LiNi1/3Co1/3Mn1/3O2 (NCM) cathode. J. Electrochem. Soc. 2016, 163, A2943-A2950. [CrossRef]

75. Ouyang, D.; He, Y.; Weng, J.; Liu, J.; Chen, M.; Wang, J. Influence of low temperature conditions on lithium-ion batteries and the application of an insulation material. RSC Adv. 2019, 9, 9053-9066. [CrossRef]

76. Kasnatscheew, J.; Evertz, M.; Streipert, B.; Wagner, R.; Nowak, S.; Cekic Laskovic, I.; Winter, M. Improving cycle life of layered lithium transition metal oxide $\left(\mathrm{LiMO}_{2}\right)$ based positive electrodes for $\mathrm{Li}$ ion batteries by smart selection of the electrochemical charge conditions. J. Power Sources 2017, 359, 458-467. [CrossRef]

77. Sotta, D. MAT4BAT Advanced Materials for Batteries Project; EU Commision: Brussles, Belgium, 2017; Available online: https://cordis.europa.eu/project/rcn/109052/reporting/en (accessed on 20 July 2019).

78. Schmalstieg, J.; Käbitz, S.; Ecker, M.; Sauer, D.U. A holistic aging model for Li(NiMnCo)O2 based 18650 lithium-ion batteries. J. Power Sources 2014, 257, 325-334. [CrossRef] 
79. National Grid ESO. 2019 Four Year Ahead Capacity Auction (T-4) Delivery Year 2023/24; National Grid: London, UK, 2020; Available online: https://www.emrdeliverybody.com/CM/Auction-Results-1.aspx (accessed on 6 May 2020).

80. National Grid. Transitional Capacity Market Auction for 2016/17; National Grid: London, UK, 2016; Available online: https://www.emrdeliverybody.com/CM/Auction-Results-1.aspx (accessed on 30 April 2020).

81. National Grid. T-1 Capacity Market Auction for 2018/19; National Grid: London, UK, 2018; Available online: https://www.emrdeliverybody.com/CM/Auction-Results-1.aspx (accessed on 30 April 2020).

82. Philippot, M.; Alvarez, G.; Ayerbe, E.; Van Mierlo, J.; Messagie, M. Eco-Efficiency of a Lithium-Ion Battery for Electric Vehicles: Influence of Manufacturing Country and Commodity Prices on GHG Emissions and Costs. Batteries 2019, 5, 23. [CrossRef]

83. Li, J.; Cheng, Y.; Ai, L.; Jia, M.; Du, S.; Yin, B.; Woo, S.; Zhang, H. 3D simulation on the internal distributed properties of lithium-ion battery with planar tabbed configuration. J. Power Sources 2015, 293, 993-1005. [CrossRef]

84. Tanim, T.R.; Rahn, C.D.; Wang, C.Y. A Temperature Dependent, Single Particle, Lithium Ion Cell Model Including Electrolyte Diffusion. J. Dyn. Syst. Meas. Control 2014, 137. [CrossRef]

(C) 2020 by the authors. Licensee MDPI, Basel, Switzerland. This article is an open access article distributed under the terms and conditions of the Creative Commons Attribution (CC BY) license (http://creativecommons.org/licenses/by/4.0/). 